\title{
Foreign Direct Investment in Latin America and the Caribbean
}

\author{
Ariel Carmona \\ Department of General Business and Finance \\ College of Business Administration \\ Sam Houston State University \\ P.O. Box 2056 \\ Huntsville, TX 77341, USA \\ (936) 294-1290 \\ maniam@shsu.edu
}

\section{Balasundram Maniam}

\author{
Department of General Business and Finance \\ College of Business Administration \\ Sam Houston State University \\ P.O. Box 2056 \\ Huntsville, TX 77341, USA \\ (936) 294-1290 \\ maniam@shsu.edu
}

\section{Stephen E. Lunce}

\author{
Business Computer Information Systems \\ College of Business Administration \\ Midwestern State University \\ 3410 Taft Blvd. \\ Wichita Falls, TX 76308 \\ (940) 397-4046 \\ stephen.lunce@mwsu.edu
}

\begin{abstract}
National and international policies have a significant influence on the changes that occur in the business environment in Latin America and the Caribbean, providing incentives for investment decisions, not only for companies already operating in the region, but for new entrants as well. Currently, foreign direct investment flows are the outcome of a combination of factors, including the international environment, national policies, and corporate strategies. Thus, this research evaluates the volume of FDI inflows into the region; the factors that attract them, including incentives and regulations; and their contribution, economical and societal, to Latin American development. This research also explores some of the potential costs of FDI, and its implications on policy options.
\end{abstract}




\section{INTRODUCTION}

Of total FDI inflows to emerging economies, a significant proportion flows to Latin America and the Caribbean. Latin American countries generally accept the fact that their benefits from FDI depend on the assumptions they make about the effect of this type of foreign investment on such variables as growth, employment, taxes, and trade. As is true for the world as a whole, Latin American countries' attitude toward FDI has become more positive since the 1980's. In fact, the Executive Secretary of the United Nations Economic Commission for Latin America and the Caribbean (ECLAC), has frequently noted that the use of FDI is the only way the region could close its economic gap with the rest of the world. Nevertheless, Latin American countries' liberalization policies, market reforms, and inflows of FDI have varied with each other and over time. Country demographics, political attitudes, and macroeconomic conditions have, and continue to strongly influence what reforms these countries enact and the success of those reforms. These determinants in turn influence companies' perceptions of countries, and consequently FDI movements. Yet, no one knows exactly what combination of foreign direct investment policies maximizes these inflows. Nevertheless, since large FDI flows do not guarantee poverty alleviation, nor positive growth effects, the mobilization of domestic resources is frequently found to be more important than attracting FDI for financing investment and stimulating economic growth.

\section{LITERATURE REVIEW}

Amiti (2003) explains that the effects of FDI depend on country characteristics, and argues that investment liberalization is expected, at least in theory, to stimulate FDI. Considering that country characteristics and trade costs change in the long term, therefore so too does the impact of investment liberalization on trade.

Albuquerque (2003) analyzes the increase of foreign direct investment to emerging market economies, and evaluates the relationship between globalization and capital market liberalization. The analysis reveals that the global factors leading to FDI have increased in importance over time for both, developed and developing countries.

Bailey (2004) describes how the combined effects of recent economic and political crises in Latin America has forced companies active in the region to make dramatic shifts in their asset positions and capital structures, and how this environment puts the region at a disadvantage in the global competition for capital.

Capital Markets Consultative Group (2003) underscores that motivations for investing in emerging markets and determinants of investment location differ among countries and across economic sectors. The report also provides considerable information on the region's recent economic and political crises, and the impact these have on FDI prospects.

Cuadros (2000) argues that FDI, rather than the amount of exports, is an important vehicle for the transfer of technology; contributing relatively more to growth than domestic investment and having a significant influence on the overall balance of trade. 
Dijkstra (2000) examines the effects of trade liberalization on the industrial development in Latin America. The study mainly explores the impact of trade policies, and whether these policies indeed can be expected to enhance host countries' short, as well as long term economic development.

Economic Commission for Latin America and the Caribbean, ECLAC, (1999) states that FDI has become one of the most important components in the globalization process of the international economy, and describes how a combination of factors determine where FDI flows to. The ECLAC 2003 report gives a thorough explanation of the current trends and investment environment in Latin America, and explains the reason as to why current corporate strategies and national policies used are hindering growth and development in the region.

Farrel (2004) makes the argument that both, incentives used to attract foreign direct investment and the restrictions placed on it, are largely ineffective. This particular research demonstrates that regardless of policy regime or the industry, FDI can benefit developing countries greatly. To make the most of it, however, these countries must strengthen the foundation of their economies, including infrastructure, their legal and regulatory environments, and the level of competition in their local markets.

Harrison (2003) analyzes how foreign firms that borrow heavily from domestic banks crowd local firms out of domestic markets. The results of this study show that foreign investors certainly ease credit constraints for firms with foreign investment, but firms that do not receive foreign investment become more credit constrained.

Hermes (2003) argues that the positive effects of FDI on economic growth can only be successful given certain characteristics of the environment in the host country. Primarily, the development of the financial system of the recipient country is an important precondition for FDI to have a positive impact on economic growth.

International Center for Trade and Sustainable Development, ICTSD, (1998) describes how FDI has played a significant role in the development of new national policies among Latin American countries, and how these developments continue to change the business environment in that region.

Kossik (2001) reveals some of the disadvantages or potential costs brought onto by FDI, and suggests that a combination of these factors presents a serious threat to the region's future economic development. The author also encourages Latin American countries to adopt other forms of capital in order to promote economic growth.

Loungani (2001) recommends that countries trying to expand their access to international capital markets should concentrate on developing credible enforcement mechanisms before even trying to attract FDI. The author suggests that countries that concentrate on improving their investment environment are most likely to be rewarded with increasingly efficient overall investments, as well as with more capital inflows. 
Morrow (2003) maintains that Latin American countries must increase expenditures on social protection in order to offset the negative aspects of actively participating in the global marketplace. Most important of all, the author suggests that Latin American countries need to create a more highly skilled and competitive labor force in order to grow more rapidly.

Simmons (2003) discusses how a country's corporate tax regime has a significant influence on the level of FDI going to that country, and how FDI then becomes an important consideration in the design of national tax policies. The main question addressed by the author is whether corporate tax policy is an appropriate instrument to attract FDI.

Trevino (2002) concludes that there are three different types of market oriented reforms currently taking place in the region, and how the benefits of policies brought onto by these reforms vary among countries. Furthermore, the author suggests that although countries may increase their FDI inflows by instituting market oriented reforms, such as trade liberalization and privatization; such inflows do not necessarily optimize their economic goals.

Willem te Velde (2003) emphasizes that while FDI may be good for development, different countries with different policies and economic factors derive different benefits and costs of FDI. More specifically, this article positions FDI in the debate of persistent income inequality in Latin America and the Caribbean.

\section{FOREIGN DIRECT INVESTMENT IN LATIN AMERICA}

During the late 1990's, Latin America and the Caribbean experienced strong growth among the distribution of world FDI flows between developing countries. Within the region, foreign direct investment flows have been largely confined to a small group of countries, mainly Brazil, Mexico, Argentina, Chile, Colombia, and Venezuela (ECLAC, 1999). Historically, foreign investment in Latin America was concentrated on manufacturing activities to supply highly protected domestic markets. To date, regional economies have been opened up and liberalized, and massive inflows of FDI have gone toward non-tradable service activities, such as telecommunications, energy, transportation and banking. Also of significance, are activities related to the exploitation of natural resources, formerly under state control, and manufacturing plants (ICTSD, 1998).

The United States has been the main source of FDI flows into the region. More recently, however, investment from Europe, mainly Spain and the United Kingdom, have grown substantially. European investors have been particularly active as participants in privatizations of state owned energy and telecommunication enterprises, and as buyers of local private banks (ECLAC, 1999).

\section{FACTORS AFFECTING THE TYPE, AMOUNT, AND EXPECTATIONS OF FDI}

Typically, determinants of investment location differ among countries and across business sectors. Nevertheless, certain general factors consistently determine which countries attract the most FDI. Overall, these factors include: growth size of the market, efficiency gains, political and social stability, macroeconomic stability, foreign investment legislation, cost and skilled 
manpower, quality and availability of infrastructure, availability of raw materials, tax and other incentives, corruption and quality of bureaucracy, and free trade and regional trade integration (Capital Markets Consultative Group, 2003). These factors can, in turn, be grouped into three main categories: (1) national policies, (2) corporate strategies, and (3) international environment.

\section{National Policies}

Generally, Latin America and the Caribbean have experienced three types of market oriented reforms that have over time contributed to the increase, or decrease, of FDI flows into the region: microeconomic, macroeconomic, and institutional. Microeconomic reforms have, for the most part, decentralized economic decision making in the region by shifting it from the state to the private sector, so that market forces drive competition. To carry out these reforms, governments have lowered trade barriers, reduced price controls, and relaxed capital account restrictions on companies' market entry and exit. Macroeconomic reforms, on the other hand, have mainly reduced inflation and stabilized exchange rates, while institutional reforms have changed the states' role from producer to facilitator, so that the private sector is encouraged and empowered to make investments (Trevino, 2002). Thus, the significant results of national policies brought onto by foreign direct investment include: macroeconomic stabilization, the opening up of trade and finance, economic deregulation, large-scale privatization, and the liberalization of regulations applying to private investments and regional integration processes. Accordingly, investment opportunities have been made public in sectors where private enterprises in general and for foreign companies in particular, were formerly subject to restrictions. In addition, the patterns of competition produced by financial and trade liberalization have awoken the interest of new entrants, and obliged multinational companies already operating in the region to rethink their corporate strategies. Many U.S. companies have also been able to capitalize on the advantages offered by export processing zones, low wages, and U.S. tariff preferences by investing or forming partnerships with local businesses. Yet, rather than being the result of new national policies, FDI reflects a major change in U.S. corporate strategies and most recently, of European firms, in sectors where there is intense competitive pressure in domestic markets (ICTSD, 1998).

\section{Corporate Strategies}

In addition to national policies, corporate strategies strongly affect the type and amount of FDI flowing to a region. There are at least four main corporate motivations for FDI, ranging from the most traditional, such as the search for natural resources and markets for goods and services, to more modern and complex goals, such as the search for efficiency through international operations, and the pursuit of strategic assets relating to the presence of superior, more advanced technologies. Yet, gaps sometimes emerge between host countries' expectations and the problems associated with these different corporate strategies (ECLAC, 2003).

With regard to FDI associated with market seeking strategies, the main expectations held by the government of recipient countries focus on the creation of new productive activities, improvements to the economy's overall competitiveness, employment to locals, promotion of new productive linkages, greater local business development, and costs and quality of local services. There is a considerable mismatch in the region between the expected benefits and those 
that have effectively been materialized in the case of FDI driven by natural resource seeking strategies, and an even larger one in the case of FDI motivated by the search for markets (ECLAC, 2003).

In relation to multinational corporations that seek efficiency, host countries aspire to improve the competitiveness of their manufactures' exports, gain access to new technologies, train their human resources, deepen production linkages, boost domestic business development, and evolve from assembly platforms into manufacturing centers. And yet the experiences considered in the region suggest that there are specific problems associated with efficiency seeking strategies including: stagnation at the level of basic assembly, concentration in static rather than dynamic advantages, limited linkages, strong dependence on imported inputs, slow progress toward the formation of production clusters, and the crowding out of local businesses. Furthermore, problems arise in relation to efficiency strategies based on cheap labor: the advantages that initially attract FDI are not sustainable over time, and the countries involved risk falling into the "low-value added trap" (ECLAC, 2003).

\section{International Environment}

One of the most notable features of economic globalization has been the increased importance of foreign direct investment around the world. The large increase in FDI flows and its distribution across countries are associated with increased importance of global factors among industrial and developing countries. This relationship is further linked to an increased integration of world capital markets following the many reforms and liberalization programs of the mid 1980's and 1990's. Most significantly, the link between FDI and globalization proves that these two variables reinforce each other. While globalization has led to higher FDI flows to a number of emerging economies, its benefits and the opportunity of receiving a greater share of global FDI flows has, among other things, motivated a number of countries to undertake further financial and trade liberalization policies (Alburquerque, 2003).

\section{GOVERNMENT INCENTIVES AND REGULATIONS ON FDI}

Countries that really want FDI do a lot of work to attract it. Different countries spend different amounts on investment promotion. Most of the time developing countries think they must not only offer incentives to attract this type of capital, but also protect their local economies by restricting the way multinationals operate. Typically, incentives include: tax breaks, import duty exemptions, and subsidized land. Yet, even as developing nations give out lucrative incentives to attract foreign investment, they are often wary of multinational companies. Research finds, however, that both, incentives and the restrictions placed on foreign capital, are largely ineffective. They are frequently counterproductive, costing governments millions of dollars annually, protecting inefficient players, and lowering living and productivity standards (Farrel, 2004).

\section{CONTRIBUTIONS OF FDI TO DEVELOPMENT AND ECONOMIC GROWTH}

The contribution to host countries from FDI can take several forms, such as the transfer of technology, human capital development, increased competition in domestic markets, and the 
generation of corporate tax revenues, among others. In principle, therefore, through these various channels, this type of capital should contribute to investment and growth in host countries. However, while foreign investment may be good for development, different countries with different policies and economic factors tend to derive different benefits from it (Loungani, 2001).

The massive inflows of foreign capital into Latin America and the Caribbean, especially to the larger economies, have helped relieve the severe balance of payments pressure experienced by many of the region's economies. In most cases, economic authorities have looked to this type of foreign capital as a relatively stable source of financing to cover external deficits, and as a mechanism for modernizing production systems, thereby improving productivity and international competitiveness (ICTS, 1998). Foreign direct investment has certainly transformed Latin America, modernizing manufacturing sectors and improving many of its services and part of its infrastructure. Examples of these are Mexico's and Costa Rica's export platforms, Brazil's much improved telecommunication networks, Argentina's financial services, and Chile's airport services and highway networks, among others (ECLAC, 2003). Privatization programs implemented in most of these economies have also provided governments with additional revenue that has helped finance their structural reform process by reducing external tensions (ECLAC, 1999). Foreign direct investment seems to have also played a significant role in influencing the size of exports, imports, and trade balance in the region (Cuadros, 2000). Local companies have furthermore benefited by copying and building on the activities of foreign competition, as foreign companies often look for local distributors and suppliers (Farrel, 2004).

\section{POTENTIAL COSTS OF FDI}

Although there is substantial evidence that foreign direct investment benefits host countries, its potential impact should be assessed carefully and realistically; developing countries should be cautious about taking too uncritical an attitude toward the benefits of FDI. Foreign direct investment is not only a transfer of ownership from domestic to foreign residents, but also a mechanism that makes it possible for foreign investors to exercise management and control over host country firms. This transfer of control may not always benefit the host country because of the circumstances under which it occurs, problems of adverse selection, or excessive leverage (Harrison, 2003). Through FDI, foreign investors gain crucial inside information about the productivity of the firms under their control. Foreign direct investors could inevitably take advantage of superior information to retain high productivity firms under their control and sell low productivity firms to uninformed investors. As with other adverse selection problems of this kind, this process may lead to overinvestment by foreign direct investors (Harrison, 2003).

\section{IMPLICATIONS AND POLICY OPTIONS}

There are still many areas in which governments and businesses could do more to improve the positive effects of FDI in Latin American countries. The variables suitable to policy action include: quality of the labor force, infrastructure, and in particular, public institutions. A government may use education, training, infrastructure, trade and investment promotion policies to improve the developmental impact of FDI. Similarly, businesses can use pay, training, industrial relations, and supplier development policies (Willem te Velde, 2003). Thus, from a development perspective, long run consequences of policies are more important than their short 
term effects (Dijkstra, 2000). Given that governments directly influence investment costs, a clear understanding of the implications of investment and trade liberalization is more likely to further facilitate successful progress toward negotiations affecting national policies concerning FDI (Amiti, 2003).

\section{RECENT TRENDS OF FDI INTO THE REGION}

According to the ECLAC 2003 report, inflows of direct foreign investment to Latin America and the Caribbean have continued to shrink for the fourth year running. Since there is still no consensus on the effectiveness of the current strategies and policies used toward FDI, the region has been characterized by abrupt institutional changes. With the latest decline in 2003, Latin America and the Caribbean turned the worst performance of any world region. The decrease in FDI inflows into Latin America has varied across subregions and countries. For instance, in Mexico and the Caribbean Basin, inflows have diminished less, while South America has been more strongly affected. Within South America, inflows were quite stable in the Andean Community, but were down sharply in MERCOSUR and particularly so in Brazil (ECLAC, 2003). Furthermore, investments in selected sectors have been hurt more by recent events. In particular, FDI in utilities and in the banking sector have been affected by greater perceptions of regulatory risks, as well as by lower than expected profits and growth prospects (Capital Markets Consultative Group, 2003).

Despite strengthening currencies, soaring stock markets, and falling country risk premiums, many countries across Latin America are less able today to enact the needed reforms and the economic policies required to sustain growth in the long run, than they were just a few years ago (Bailey, 2004). Furthermore, initial reforms generated high expectations that in many countries have not yet been matched by growth in real wages, employment, and public services. Many of these reforms have, in fact, directly contributed to the economic insecurity of certain population groups. Trade liberalization has exposed firms to more intense competition and hence to pressure for cost efficiencies (Morrow, 2003). Most important of all, the vast majority of the population in the Latin American region feels apprehensive to current market reforms because of their inability to obtain adequate education for their children, increasing crime, and in many cases, the rising prices of essential goods and services previously subsidized by their local governments. Perhaps most responsible for this insecurity is the fear of unemployment (Morrow, 2003). Consequently, the population's discontent with persistent inequality despite a decade of reforms, combined with the recessions that hit many countries, have fractured political consensus regarding market oriented policies. Unfortunately, this political volatility places Latin America and the Caribbean at a disadvantage in the global competition for capital (Bailey, 2004).

\section{DISCUSSION AND OBSERVATIONS}

Foreign direct investment in emerging markets is perhaps the most controversial form of globalization. Possibly the biggest benefit of foreign direct investment, and one seldom discussed, is its ability to raise local standards of living. Local consumers are without a doubt, the biggest beneficiaries of this form of investment. Generally, they enjoy lower prices or a better selection of goods and services, or both after foreign companies arrive. Prices fall because foreign players improve a sector's efficiency and productivity by bringing in new capital, 
technology, management skills, and by forcing less efficient domestic companies either to improve their operations or to exit the local markets.

Developing and developed countries generally seem to agree on the benefits and desirability of foreign direct investment. There is now consensus among governments that this type of investment is desirable, even essential, for economic growth and poverty reduction. Normally, however, the problem seems to be defined as not getting enough of it. Just more volume, however, is not likely to deliver sustainable growth. Foreign direct investment could, without a question, be a potential factor in promoting development. However, the exploitation of this potential requires an appropriate economic climate. In the absence of such a climate, FDI can thwart rather than promote growth; it may serve to enhance the private rate of return to investment by foreign firms, while exerting little impact on social rates of return in the recipient economy. Without proper governance and management, FDI can additionally generate a high toll in environmental, health, and other social costs, and may not even deliver much in long term economic benefits. Thus, the benefits of FDI are neither exclusive, not necessarily positive. Furthermore, while positive outcomes from FDI in host countries are likely, they are far from automatic or guaranteed. Receiving countries should therefore, not only worry about attracting this type of capital, but must also pay close attention to its potential costs.

Moreover, the fact that tax reductions or incentives are effective in attracting FDI does not automatically mean that governments should pursue these policies. More specifically, Latin American nations should abandon their incentives and regulations toward FDI, and concentrate instead on improving the quality of their institutions, labor force, and infrastructure. Although there are many variables beyond the control of policymakers that influence where FDI flows to, the quality of a host country's institutions clearly play a prominent role in determining where that investment ultimately goes. Of similar importance is reducing economic insecurity through the implementation of better policies and programs that increase social protection and improve key social services. Within the region, there is growing recognition that competitiveness in the global economy and rapid technological change require a well educated and dynamic workforce. Thus, improving education throughout Latin America is crucially important in both economic and political terms.

\section{CONCLUSION}

Foreign direct investment has increased rapidly across the world in recent years, and Latin America has been no exception. However, different countries have had very different degrees of success in attracting and benefiting from this type of investment. While competing for FDI by offering tax and other incentives can sometimes be effective in attracting investors, improving the quality of a country's institutions appears to have a much greater impact. Perhaps most importantly, competing by addressing such fundamental issues as educational and institutional development affects the type of FDI that comes into a country, and the benefits the country derives from those investments. Clearly, there are causal relationships between the economic determinants, hosts countries' expectations, and the problems that arise from corporate strategies. Latin American countries should therefore, define what they expect from FDI, and the role it will play in the context of their national productive development by setting priorities, designing 
appropriate policies, establishing appropriate institutions for meeting their primary goals, and targeting specific types of foreign direct investment.

\section{REFERENCES}

Amiti, Mary \& Wakelin, Katherine (2003). “Investment Liberalization and International Trade.” Journal of International Economy. 61(1), p. 101 [Online] Available: http://search.epnet.com/direct.asp?

Albuquerque, R., Loayza, N., \& Serven, L. (2003) "World market Integraion Through the Lens of Foreign Direct Investors.” The World Bank Group, February 2003. [Online] Available: http://econ.worldbank.org/files/26993_wps3060.pdf

Bailey, Jed (2004). “What Next for Latin American Power Market?” Journal of Structured \& Project Finance. 9(4), p. 60 [Online] Available: http://search.epnet.com/direct.asp

Capital Markets Consultative Group (2003). "Foreign Direct Investment in Emerging Market Countries." The World Bank Group, [Online] Available: http://www.worldbank.org/prospects/workingpapers/fdi-dilek.pdf

Cuadros, A.; Orts, V. \& Alguacil, M.T. (200) “Re-examining the Export-led Growth Hypothesis in Latin America: Foreign Direct Investment, Trade and Output Linkages in Developing Countries.” European Trades Study Group. University of Nottingham, [Online] Available: http://www.ets.org/ETS2000/Papers/Cuadros.pdf

Dijkstra, Geske A. (2000) “Trade Liberalization and Industrial Development in Latin America.” World Development, 28(9), p. 1567. [Online] Available: http://ep.eur.nl/handle/1765/469

Economic Commission for Latin America and the Caribbean, ECLAC (1999). "Characteristics of Foreign Direct Investment in Latin America.”[Online] Available: http://magnet.undp.org/new/pdf/PDFscomplete/ECLAC2.pdf

Economic Commission for Latin America and the Caribbean, ECLAC (2003). "Foreign Investment in Latin America and the Caribbean,” [Online] Available: http://www.eclac.org

Farrel, Diana; Remes, Jaana K. \& Schulz, Heiner (2004). "The truth about foreign direct investment in emerging markets.” McKinsey Quarterly, Issue 1, p.24 [Online] Available: http://search.epnet.com/direct.asp

Harrison, Ann E. \& McMillan, Margaret S. (2003) "Does direct foreign investment affect domestic credit constraints?” Journal of International Economics. 61(1), p.73 [Online] Available: http://search.epnet.com/direct.asp

Hermes, Niels \& Lensink, Robert (2003). "Foreign Direct Investment, Financial Development, and Economic Growth.” Journal of Development Studies. 40(1), p. 142 [Online] Available: http://search.epnet.com/direct.asp 
International Center for Trade and Sustainable Development, ICTDS (1998). "Characteristics of Foreign Direct Investment in Latin America.”[Online] Available: http://www.ictsd.org

Kossik, Robert (2001). "Recent Trends in Foreign Direct Investment in Latin America.” The National Law Center for Inter-American Free Trade. [Online] Available: http://www.natlaw.com/pubs/spmxfi6.htm

Loungani, Prakash \& Razin, Assaf (2001). “How Beneficial is Foreign Direct Investment for Developing Countries? International Monetary Fund. Finance \& Development. [Online] Available: http://www.imf.org/external/pubs/ft/fandd/2001/06/loungani.htm

Morrow, Daniel. “The Political Challenges of Advancing Economic Reforms in Latin America.” Carnegie Endowment for International Peace. Economic Development Institute of the World Bank. [Online] Available: http://www.ceip.org/Programs/polecon/latin1.htm

Simmons, Richard S. (2003). "An empirical study of the impact of corporate taxation on the global allocation of foreign direct investment." Journal of International Accounting, Auditing, and Taxation. 12(2), p. 105 [Online] Available: http://unxl.shsu.edu

Trevino, L., Daniels, J., Arbelaez, H., \& Upadhyaya, K. (2002). “Market Reform and Foreign Direct Investment in Latin America,” International Trade Journal.16(4) p. 367. [Online] Available:http://search.epnet.com/direct.asp

Willem te Velde, Dirk (2003). "Foreign Direct Investment and Income Inequality in Latin America.” Overseas Development Institute. [Online] Available: http://www.odi.org.uk.iedg/Meetings/FDI_Feb2003/fdi_la_dwtv.pdf 